\title{
An Interview with Bharati Mukherjee
}

THIS INTERVIEW took place over a two day period just after Thanksgiving, 1989, in Iowa City, where Bharati Mukherjee had come to read from her latest novel, Jasmine, and also to spend the weekend with her husband, Clark Blaise, who was teaching at the Iowa Writers' Workshop. It was a hectic period for her. The Middleman and Other Stories had recently won the 1988 National Book Critics Circle Award for Fiction; Berkeley had offered her a Distinguished Professorship, which she accepted; and she was promoting the new book, which was critically praised when it appeared earlier that fall. We met in Clark's temporary residence, a sublet apartment arranged through the Workshop. The living situation-with Bharati dividing her time between New York and the west coast, and Clark stationed in the midwest - was emblematic of a twenty-seven-year marriage which has held up through the transience of a teaching-writer's life. Because they had been forced to accept jobs wherever the jobs had appeared, they often lived apart for long periods of time, incurring huge telephone bills and thousands of air miles when they commuted back and forth.

Bharati Mukherjee was born into a well-to-do Indian family - her father was a prize-winning chemist-in 1940. Since coming to the Writers' Workshop in 1962, she has lived largely in the U.S. and Canada, returning home to India every summer for a visit. After earning her MFA, she completed a PhD in English Literature, taught at McGill for several years following their move to Canada, and recently has taught in New York at Queens College and Columbia University. Her teaching has limited her writing time. Nevertheless, she has produced three novels, Jasmine (1989), Wife (1975), and The Tiger's Daughter (1972); two story collections, The Middleman (1988), and Darkness (1985); as well as two works of nonfiction, Days and Nights in Calcutta, about her return to India, and The Sorrow and the Terror, an investigative report into the 1985 Air India bombing in which 323 people were killed. The nonfiction books were written in collaboration with Clark Blaise, who is the author of $A$ North American Education (stories), Lust, Lunar Attractions (both novels), and Resident

Michael Connell, Jessie Grearson, and Tom Grimes were the interviewers. 
Alien, a recent collection of short stories and autobiographical essays. Days and Nights in Calcutta is currently being made into a movie, and the two of them were working on the screenplay and on a piece about Salman Rushdie, when we met.

For all the incarnations Bharati Mukherjee has gone through-from Bengali Brahmin to workshop student, from working mother to celebrated author-she is a woman who seems unshakably sure of who she is. But the idea of transformation, of life being a process of almost constant and radical evolution, has been one of the major themes of her work.

TIR: You said at one point, "There are no harmless, compassionate ways to remake one's self . . . we murder who we were so we can rebirth ourselves in the images of our dreams." Do you see violence as necessary to a transformation of character?

BM: Yes. And I can see that in my own life it's been psychic violence. In my character Jasmine's case it's been physical violence because she's from a poor farming family. Plus terrorism is a virus of the ' 80 s, so there is the initial violence of the village, where her husband dies in a fire bombing. Because she is an undocumented, poor alien, she necessarily goes through a kind of physical harassment that someone like me was exempt from. But just growing up in my Calcutta, the daughter of a very rich factory owner in a time when West Bengal, and especially Calcutta, was becoming Communist, I had to personally experience a great deal of labor violence and unrest. There were many times when I went to school with what we used to call "flying squads." Military policemen in vans in front, special policemen in vans in back, our car, with chauffeur and bodyguard in between so we could, the three sisters, take part as pretty maidens in gondoliers. Gilbert and Sullivan light operas, etc. I'm coming out of a 19thcentury world, and have witnessed a lot of violence for myself which didn't physically scar me-I mean, no one threw acid on my face as was feared. But Jasmine actually encountered it, because it's not a realistic novel. It's meant to be a fable.

TIR: Can we talk about your upbringing for a bit?

BM: Certainly.

TIR: Is Bengali your native language? 
BM: Yes.

TIR: You spoke it before you spoke English?

BM: Yes. I was unilingually Bengali for the first three years of my life. This was before Independence in 1947, the tail end of the British Raj, when the Raj already knew it was crumbling and there were a lot of nationalistic struggles in and around Calcutta.

I went at age three to a school run by Protestant missionaries and that was a sort of bilingual school for elementary schoolchildren. The courses were taught in Bengali, but they introduced English. That's how I knew mat, bat, cat - more complicated sentences, actually - by the time I went to school in England at age eight. And that was the three years in England and Switzerland when I felt I was totally bilingual. I could operate in both languages equally well. And I could speak English like a Cockney when necessary, or establishment English because it was a fancy Sloane Square school that I was sent to. When I came back to India, to Calcutta, to a very special girls' school called Loretto House run by Irish nuns in independent Calcutta, I became less Bengali-speaking.

TIR: Your English had taken over?

BM: Yes.

TIR: Was this a matter of choice, or had you just lost the Bengali by then?

BM: I hadn't lost it, but there was an instilling of value systems, cultural value systems, which now strikes me as so ironic. The nuns were Irish to begin with, but in the outpost, they became more British than the British. And during the schooldays we were taught to devalue - I was going to say sneer at, but that's putting it a little too strongly-Bengali plays, Bengali literature, Bengali music, Bengali anything. And then we went home-I came from a very orthodox, very traditional family - so we had to negotiate in both languages. But, as I'm sure happens with minority children who are being channeled into fancy prep schools and all, it created complications within the Hindi community, within the Indian upper-class community of my generation. It wasn't until I became a graduate student at Baroda (where, if I wanted to get a Master's degree in English, I also had to take either a regional Master's in a regional Indian language, or in ancient Indian culture) that I really came to know the marvels of Hinduism. No, I knew Bengali, but the culture itself I hadn't really studied formally until then. I just imbibed it by osmosis. 
until then. I just imbibed it by osmosis.

TIR: How did you happen to come to the Iowa Writers' Workshop? BM: Well, this is the story I've told a lot of newspaper people. My father was a very expansive sort of man, very sociable, and so every foreigner who came through our town-European, American - was always invited to dinner at our house. And in 1960, there was a group from UCLA (Project India or something like that) and there was a young drama professor who was probably the first black man my father had even seen. He came with a couple of his students and my father said to him, "I want this daughter to be a writer. Where do I send her?" And the guy, out of the blue - I mean, he was from California, what did he know? - said, send her to Paul Engle in Ames, Iowa. And my father sent off this letter, just Paul Engle, Ames, Iowa, and the letter did reach Paul, and he said come and I came. The PEOs arranged the scholarship. There was a PEO lady who was in town because her husband was a Fulbright scholar of history, and so she said - she was Paul Engle's neighbor I think - let me write you a letter of recommendation, and so I think that helped me get the scholarship as well. And then twenty-five years later, in Seattle last month, Clark and I were giving a reading in a bookstore called Elliot Bay, and there in the audience was the lady who wrote the letter of recommendation. Isn't that wonderful?

TIR: How early did you meet each other and become readers for each other? Was that soon after you got here?

CB: I entered in February of '62, she entered in September '61, so I was behind her by a semester. And we married in September '63. We've been married twenty-seven years. So we really had that summer of '63BM: - that we didn't show each other our writing.

CB: No. We really didn't read each other's work. I mean, I'd readBM: - but only as someone, you know worksheets . .

CB: Yes, it wasn't really during the workshop years that we read for each other. But immediately afterward, yes.

TIR: So you do read each other's work first now? Are you each other's first readers?

BM: Clark is my first reader. I delay a lot.

CB: There's a lot she hasn't read. 
BM: No, the early stories I find so painful, and I know they're autobiographical, so it took me a long time to deal with that. A couple of years ago Clark and I gave a reading in Gainesville, Florida, and he took me to see many of the houses and the areas where he had grown up and where the stories are set. I said, "This doesn't seem so bad, so nightmarish." TIR: Clark, in Resident Alien, you said that your move to Canada in the mid-'60s was "your imperialism, totally." Bharati was against it?

CB: She would never have gone.

BM: I would never have gone. I cried as I was crossing the border.

CB: The tears of Windsor.

BM: Right. America represented a kind of glitziness - as in Jasmine - a chance for romantic reincarnation, whereas moving to Canada was like going to England, a step backward to an old world, a hierarchical society. CB: Whereas Canada for me, is, in some ways, a solution to my identity crisis. America was the place where I knew vast suffering, and vast turmoil and chaos. But in Canada I had a certain place, in a certain world, with a certain identity. I belonged. And I knew I belonged.

BM: That's interesting, because I wanted to get away from that sense of belonging. I didn't want anyone to know where I fit in, so I could be whoever I wanted to be, anywhere, and I could keep moving.

CB: Whereas with my name, Blaise, a French-Canadian name, I can only be French-Canadian. She can only be Bengali Brahmin with her name, but here nobody knows that. And to her, it's something to flee. It gives me the only identity I have.

TIR: So that time in Montreal, then, you said it gave you a sense of identity? Did that catalyze your imagination? Because that's when you started writing a lot of fiction.

CB: Oh, yes. It empowered me. And leaving that world has had a great negative effect.

TIR: And with Bharati it's the opposite effect?

BM: Well, I wouldn't say opposite. In the beginning of our stay in Canada, I wrote The Tiger's Daughter, Wife, and Days and Nights in Calcutta. It was in the mid-'70s, 1973, that we started to see the visible effects of racism. Five thousand Ugandan Asians, with British passports, were allowed into Canada as a favor. The Canadians' favor to the British gov- 
ernment. Immediately, there was a backlash against what they called the "visible minority." Even though these people were not on welfare, were in fact professionals and businesspeople, their presence created an atmosphere of hostility into which the person on the street was drawn. I started to notice on a daily basis little incidents in my corner Woolworth's in Montreal, or in hotel lobbies, on buses, things just not being quite right. Then it ballooned into very vicious physical harassment by 1977, 1978.

CB: Especially when we moved to Toronto, where it was centered. Not Montreal.

BM: Where people were being thrown on subway tracks, and things. We had endless - everyone from that era has endless - personal litanies of discrimination.

TIR: You call them "crippling assumptions," somewhere in your work. BM: About my being taken for a smelly, dark, alien other. Yes. You never got the benefit of the doubt, if you were a Canadian citizen of Indian or South Asian origin.

TIR: Did that eventually catch up and paralyze your work? There's that ten-year gap between Wife and Darkness.

BM: I think it must have. I was writing a lot of scholarly essays, and I was doing administrative work-Director of Graduate Studies, McGill. Human rights work. But I was so angry all the time, and getting more and more shrill. And becoming almost paranoid, so that any incident of disdain wasn't simply rudeness, casual rudeness of a shop salesperson. It had to be race.

TIR: How about the logistics of doing The Sorrow and the Terror?

CB: That was a real schlep. We were living in Astoria, Queens, and we were teaching. Bharati was teaching in Montclair, New Jersey, and I was teaching at Columbia. I would finish on Thursday and immediately get in the car and drive up to Toronto, a twelve hour drive, and start interviewing various family members, or policemen, or whoever wanted to talk. And each of the families would suggest I talk to Mr. So and So, so that I was generally taping these people-

BM: - and sometimes we would have two and three interviews with the same people. You do so many more interviews than you can really use. CB: Yes. By then we had eighteen or nineteen various cassettes, and we 
were, of course, having to read, and in some cases liberate, some secret documents from government files. Fortunately, we had friends well placed in the police, and the International Air Transport branch. So we had all of the standard texts. Enormous stacks of material. And personal memories of the people.

BM: We also went to Vancouver to talk to the alleged extremists.

CB: See, the whole thing started in Vancouver. That's where the Khalistanis are.

BM: And they were very forthcoming. It's like a network, so that once someone has approved of you as journalists, then people who were reluctant to talk in the beginning are all fighting among themselves for access to you.

CB: On the weekends when we didn't get to Canada we stayed in New York. The world Sikh organization, before they got kicked out, had its major offices in New York. Sikhs were inviting us to dinner parties. So we were going into the wealthy areas of New York and Westchester. And in Brooklyn there was a major trial, the Birk trial, which starts the book off. We were at that trial for almost three months on a daily basis. Then we had to transcribe all those tapes, and then go to Vancouver to talk to all those people, and then go to Ireland to be there for the tripartite-Irish, Indian, Canadian - unveiling of the memorial. And then talking to all the Irish, and the hospital people, and the diplomats . . .

BM: The morgue.

CB: Right, the funeral homes, the coroner, Mr. Reardon.

BM: Who was wonderful. The coroner was wonderful.

CB: He would raid the coroner's reports on the bodies. He also gave us the seating plan on the plane which was how we were able to say who was sitting where.

BM: It was an extraordinary amount of work. And because we were not newspaper journalists, we didn't have an editor saying, "This is not a sexy story. Move on to Beirut, or something else." So we gave ourselves all the time we needed to follow our hunches and leads. We discovered a great deal more than the Toronto Globe and Mail, and the local Canadian papers. Or maybe they didn't want to discover.

CB: Then we went down to Atlanta, where I was teaching at Emory, and we wrote that month. 
BM: But the logistics. Clark had done some of the interviews, I had done some myself, and we had done some together. We had an enormous amount of material which we then parcelled off into different parts to do the first draft. Then we edited. I edited his, he edited mine. Every single word was somehow approved by both writers. And there were so many legal pressures. Every word had to be gone over by the Penguin lawyers, and we had to change certain things in order to make sure we couldn't be sued. There were sources who turned out to be very left wing, or Communist, who also gave us very good leads in the hope, we realized at the last minute, of dissemination of Communist-

CB: - because you know, these are all Sikhs. The real bloody battlefield in Punjab is between the left-wing and the right-wing Sikhs. The Khalistanis were very right-wing, and the first people they went out and killed were Congress and Communist Sikhs, so you have a lot of Sikhs in Canada who are anti-Khalistani. They are good, liberal, humane civil libertarians, for the most part, but they also have their own agenda. They want to destroy Khalistanis, because of long-standing ideologies. So they were giving us information which all turned out to be very good. Real inside information. They had it on file.

BM: Even though they were unemployed machinists, and so on, they had telexes-

CB: - Fax machines in the bedroom, wonderful stuff. You're talkin' real high intrigue here. These are all guys who have been set upon by other Sikhs; they have skull fractures; they're veterans of being set upon by field hockey sticks.

BM: And so once the book came out, and they discovered we were against terrorism, we were denounced from the pulpit of Sikh temples. It was really very frightening for a whole year. We also detected among the same liberal, middle-class white Canadians a kind of racism against the successful Hindus. So that suddenly the terrorists became the salt-of-theearth, farmers -

CB: - because the terrorists are illiterate, don't speak English, are dirt poor-

BM: They are not really dirt poor.

CB: They have no graces, they have no sophistication. Whereas the people who were killed were all these suburban $\mathrm{PhDs}$, money managers, 
who were sort of Tory voters, too. So suddenly the liberals are saying, we are defending all of these upper-middle-class-

BM: -Uppity Wogs!

CB: Uppity Wogs with their half-million dollar homes, and their children who are all getting $98 \mathrm{~s}$ on their test scores. So we were considered elitists, elitist Hindus, and Americans, supporting those victims against those salt-of-the-earth, poor, ignorant, hardworking, good guys. I mean that is exactly what Sikhs are. They are loyal, hardworking, good guys in a particularly rough way.

TIR: What about writing Days and Nights in Calcutta? Did you write each section separately and then exchange them?

BM: No.

CB: Just separately, period.

BM: The contract, in fact, with Doubleday was that we would not discuss our experiences with one another, we wouldn't exchange notes. It was to be kept very separate.

TIR: You had the contract first, then, before you wrote it?

BM: Yes. At the end of the year, after we had our manuscripts, we had to sit with an editor in New York and decide whether to do alternating chapters, how to put it together. And the idea was that it would be alternating chapters.

CB: Originally.

BM: In the original contract, it was called The Bengal Journals. It was meant to be simply the record of a day-to-day account of two people going to India -Clark for the first time, me having to reconnect with the family. Then when we started writing, I realized that it wasn't just the account of one year I wanted to talk about, but that the urgency was my life, the life of a particular class at a particular time in Calcutta's history. In many ways I was very much like all my school friends in Loretto House, and in some very basic ways I was different. It was while writing Days and Nights (a traumatic book for me to write) that I realized for all the trouble I was going through in Canada, it was still the new world that I wanted to live in, and that the old world was dead for me. Emotionally, and inspirationally. There were just so many aspects of India that I disliked by then. So a lot of my stories since are really about transformation-psychological transformation - especially among women. As opposed to economic transformation. 
CB: Which would be more an Asian man's situation. He comes for economic transformation, and he brings a wife who winds up being psychologically changed. This is one of the tragedies you see being played out in all the New Jersey shopping malls these days. The Indian women walking around in the malls with nothing to do all day, while the men are out busily making money. The men have a sense of accomplishment. They have no idea of staying here. The idea is saving money and going. But they don't realize the women have been transformed.

TIR: It comes up in the stories. The men have a sense of "nostalgia."

BM: Yes. It's reactionary. Their image of India is frozen in the year they left the old country. In 1989 they're still thinking of the society being in the late ' 60 s or early '70s. This is causing a lot of conflict within the South Asian immigrant families, especially for the children. In their minds they are Americans. But the parents want them to do well in school, then come back and be culturally perfect Indians.

TIR: How did you structure the screenplay for Days and Nights? Did you have the Sy Field "page 23 plot twist" sort of thing?

BM: No, not at all. We came into the screenwriting unprepared, ignorant and innocent. It was meant to be a feature film, so the first thing we learned, in the initial writing of treatment, was that we must not think of these characters as us. So the moment that we gave them separate names, Lela and Colin - it came to me in the middle of the night. I said, "HeyCB: -Colin, wake up."

TIR: You gave yourself a lover?

CB: "I know what we need."

BM: Right. I said "what we need" because then I realized that would then be a way of discarding India. By discarding the lover, Lela would be discarding India. The moment we got separate names we could look at the characters and their stories in a certain way. We realized, through trial and error, that in film you have to forget the text, forget the book and start afresh. You have to grind down the characters so that they can come up again. We learned phrases like "the arc," and "payoff," and so on. Every scene had to have some dramatic purpose so it was a very slow process for us. As novelists, we can work very subtly and build in lots of variations, but the director, who really held our hands through the whole process, made us see that you have to prove whatever you want to prove about 
the characters or situation in one scene. Instead of having it like a novel, with many little scenes and foreshadowings.

Clark often says, "Work in threes." Has he said that in workshop? Here we learned to forget the building up of plot devices and do it in one shot. And we learned how to use minor characters differently. For example, I had a very nice friend, out of many nice friends in Days and Nights, that I picked as a foil. But that friend, who in the novel, the text, is an interesting enough character with roundedness of her own, became too rounded a character in the screenplay and the director made me cut her scenes because there shouldn't be that much competition between Lela and the friend. And also, it turned out that some of the gutsy confrontation scenes that we were going to have between lover and husband just weren't necessary in the final version. So finally it's meant to be an "art" movie. CB: It has kind of a Rashomon structure, like the book. You follow a joint part initially, then there's my twenty-five minutes of India through my eyes, and then you turn back to the beginning through her eyes, with a very different texture and feeling, of course, trying to avoid any sort of ennui that can set in when you make transitions. Very quickly, as soon as Lela's part starts off, we had to start feeding fresh, new material to the viewer. Colin's stuff ought to have been interesting because it was fresh and new, the first time you saw it. Lela's stuff has to be even more interesting, in a sense.

BM: Because you already know the story line.

CB: Right, you know the story line, that there's going to be tension and that there's going to be a lover. The viewer knows all these things, yet how do you keep it all interesting? In fiction there is a structure where you can actually give away your whole plot in the very first paragraph and still tell a whole novel, like Ford's The Good Soldier. But that is hard to do in film.

BM: And in terms of collaboration, the script-writing meant that it wasn't just Blaise and Mukherjee, but there was a story editor, hired briefly, and the director. The story editor was saying to Clark, "We don't want Colin, who is a writer, educated," because that is going to turn off the audience. We need to see him as a truck driver. We had to fight that kind of detail.

TIR: So what does Colin become? 
BM: He remains a writer. And an elitist writer to boot.

CB: We put an Expos cap on him. He walks through his scenes in Calcutta with an Expos cap on.

TIR: Bharati, do you believe in reincarnation?

BM: That's a tough question. This is where the English and British training of my post-colonial years has been very damaging. I've always found it hard to cope with what are the very basic tenets of Hinduism. But yes, I suppose, if you were asking me casually, I would say, as a believing Hindu, yes. But it has been a real struggle. My way of dealing with it has been to say, like in my novel Jasmine, we are re-inventing ourselves a million times. I like to think that Hinduism is a kind of geophysical vision, rather than a religion, in the conventional Western sense. When we talk about reincarnation it might be as simple as saying that once the body dies and is cremated, the charred bits going up in smoke become something else. They are absorbed in water or are absorbed on the land. I don't know.

TIR: That sense of the metaphysical and the literal seems to run through your work. Do you see immigration as an experience of reincarnation?

BM: Absolutely! I have been murdered and reborn at least three times; the very correct young woman I was trained to be, and was very happy being, is very different from the politicized, shrill, civil rights activist I was in Canada, and from the urgent writer that I have become in the last few years in the United States. I can't stop. It's a compulsive act for me. It's a kind of salvation, and the only thing that prevents me from being a Joyce Carol Oates, and I'm not talking about quality, but just that need to create, is schedule.

TIR: You seem to write about similar characters leading different lives. Does this tie into your idea of reincarnation?

BM: I must be interested in certain types of characters (Maya/Angela/ Jasmine) and so they keep recurring to me in different ways. Or what she thinks is the right thing to do has changed as I have changed, as a person. TIR: Did you plan, for instance, to expand the short story "Jasmine" into the novel?

BM: No. I didn't know when I finished the story that it would become a novel. It was just that this was a character that I fell in love with. This was a character I would have liked to have been. She became a deeper, more 
complicated character in my head, over the months, so I had to give her a society that was so repressive, traditional, so caste-bound, class-bound, genderist, that she could discard it in ways that a fluid American society could not. I had to find the metaphors and symbolic location for her, and then the right series of events to dramatize the ideas. A novel really gives you so much space to fulfill the character's dreams, so I was able to build in three different sets of responses to being in that position of having to clean up after white people. One is an island woman who came from a middleclass family, just like the Jasmine in the story, but who resents the social demotion. Whereas Jasmine, in the novel, doesn't care about social demotion. And Jasmine in the story also sees all this as opportunity, and I guess part of this is autobiographical impulse.

The kinds of women I write about, and I'm not generalizing about women in the South Asian community here, but the kinds of women who attract me, who intrigue me, are those who are adaptable. We've all been trained to please, been trained to be adaptable as wives, and that adaptability is working to the women's advantage when we come over as immigrants. The males function very well as engineers or doctors or whatever, and they earn good money, but they have locked their hearts against mainstream culture. They seem to be afraid of pollution. Their notion of India seems to have frozen in the year in which they left India, and they don't want to change. Change is frightening; they are like mini-Ayatollahs in some way. They don't want to be part of history and flux. Whereas the women are forced to deal with Americans in the small daily business of life. They have to go to the grocery store and actually interact with real Americans, so they have to attend PTA meetings, be in car pools, and so on. For an Indian woman to learn to drive, put on pants, cash checks, is a big leap. They are, as Clark was saying, exhilarated by that change. They are no longer having to do what mothers-in-law tyrannically forced them to do. And they are free to set up businesses, which they are doing throughout the country. And these new Indian wives are apparently heavy duty users of day care centers, so they can run their boutiques and businesses.

TIR: The men always seem to be translating dollars into rupees, and thinking, "Well, I can always go back and buy this condominium and I'll be safe." But the women seem to be going further and further into America. From Darkness through Middleman and into Jasmine, there seems 
to be this flight into the American experience.

BM: I don't know if all my women characters make that flight into America successfully though. I think of Maya as a very lost, sad character, who really went out and married a white man and is so well attuned to women intellectuals, her colleagues, but at the same time there is that desire for a wholeness, nostalgia, that India and Indian traditions promised. And so, she's the one who is going out and seeking an advertised, perfect Indian groom, and it works out in strange ways for her. For her, the turn comes when the guy without arms, the lover without arms, calls her May. Suddenly, she snaps. No, I'm not May, I'm Maya, and people from the outside don't understand me. Whereas a Jasmine, in the short story, is someone who wants to make-is hurtling into an unknown America.

TIR: And bringing turmeric with her. You were talking about what they take. Especially in Jasmine, cooking for the community. And she has on sneakers.

BM: Yeah. I want that sense of two-way traffic, that she has transformed America, too, in her ways. Sometimes fatally.

TIR: When you were talking about the psychological transformation that occurred in Indian women, we contrasted it with the nostalgia and the unwillingness to change in Indian males. Were your characters in Wife manifesting the darker side of psychological transformation? And what of the more positive benefits of psychological transformation?

BM: I think of myself as a very comic writer and that finally, in a bizarre way, my stuff is meant to be optimistic. Dimple, if she had remained in Calcutta, would have gone into depression, and she would have found a very conventional way out for unhappy Bengali wives-suicide. Bengal has, together with Gujat, the two highest incidences of wife-suicide. But in the United States, she suddenly learns to ask herself "self"-oriented questions. Am I happy? Am I unhappy? And that, to me, is progress. So, instead of committing suicide, turning the society-mandated violence inward, she, in a misguided act, kills the enemy. So, of course, I'm not approving of murder.

CB: But it's a positive act.

BM: It's meant to be a positive act. Self-assertive.

TIR: And in Jasmine there is the same turning from suicide. 
BM: She comes to commit suttee, quite literally, "burn the suit"- which is a symbolic body of the husband - and herself, and then because of the way Half-Face assaults her, she says no. She becomes Kali, the goddess of destruction.

TIR: Right, she cuts her tongue.

BM: Because Kali has her red tongue hanging out. All Bengalis, including me, are Kali worshippers. She is the goddess of destruction, but not in a haphazard, random way. She is a destroyer of evil so that the world can be renewed.

TIR: You were talking earlier about different forms of power, acquiring and expressing power, the different forms of power for women, and it struck me that in your work there is power even in the re-straining and pouring of tea.

BM: Well, certainly all my life, I realize now, all my writing life, I've been interested in the ways people acquire power, exercise power, and even more importantly, I realize, relinquish power or are forced to relinquish power. One of the novels that I started but never finished, is about an Idi Amin kind of figure. The title of this unfinished manuscript is The Father of His Country. I guess in different ways I am always trying to find a metaphor, the right character to tell the story, or variants of the story of how to acquire power, exercise it and then have it taken away from you, or voluntarily give it up. For some of the women characters in my stories, fasting is a way of exercising that power. When you have nothing really, withholding food can become the only way to exercise power. What is regarded as passivity, or was regarded in Wife as passivity, by feminist $M s$. magazine-type readers in 1975, was meant to be read very differently. My women are utilizing the tools at hand. I did not build, deliberately build into the center of Wife, the Ms. magazine way as the "right" way with everyone else defective in their ways of fighting domination, whether it is male or class or poverty. I want to think that power is my central obsession.

TIR: Do you mean that as a positive thing, or sometimes positive?

BM: Sometimes positive, sometimes negative. In "Loose Ends," for example, the Vietnam vet, Jed Marshall, when he realizes that America isn't the way it used to be, and that he is nobody in the eyes of this young woman who helps run the motel, that is when he snaps, seeing himself as 
the "other." Seeing himself through the young Indian-American's eyes. So some of it is pleasant, some of it is comic, I like to think, and some of it is, for the women characters usually, heady stuff.

TIR: There seems to be a resistance to a Western idea of feminist thought or philosophy in your work.

BM: Yes, I think a resistance does run through my work. For some nonwhite, Asian women, our ways of negotiating power are different. There is no reason why we should have to appropriate - wholesale and intactthe white, upper-middle-class women's tools and rhetoric. Especially rhetoric. I think that 1975 was a very dogmatic, prescriptive year in American feminism and they could not stand any deviations or any rebellions. There were a lot of run-ins. I had a lot of run-ins. I'll give you a small example of the kinds of misinterpretations, in terms of feminism, that my stories go through. "Jasmine," the story in The Middleman, ends with young Jasmine, this Caribbean-Indian girl, making love to her white boss on a Turkish rug in front of the fire, in a room which she cleans during the day. Reviewers loved that story generally and loved that scene, but they saw Jasmine as an exploited young woman, and the white male, her employer, as a sleazy boss who is taking advantage of this poor, innocent, put-upon, au-pair girl. Whereas I meant for Jasmine to know exactly what it is she wants and what she is willing to trade off in order to get what she wants. She is in charge of the situation there. The man has succumbed to lust and to her sexuality. Jasmine is a woman who knows the power, is discovering the power of her sexuality. If there is a villain in that story, it is Lara, the wife, whose feminism and professionalism are built on the backs of underemployed Caribbean or Hispanic au-pair girls. But no one got that, you see. It was meant to be a very political ending.

TIR: The political, or feminist, response to Wife in 1975, was pretty harsh, wasn't it?

CB: When Wife came out, Ms. magazine had a review which said, "Some books can be allowed to die, but others have to be killed." That was their attitude toward Wife.

BM: They were really angry.

CB: She's always had a problem with American feminists.

BM: They felt that I was impartially nasty. "Miss Mean-mouth" they called me. But I do disapprove of the imperialism of the feminists, Ameri- 
can, and perhaps European feminists, but especially the American feminists of the mid-'70s who felt that they could go to Iran and tell the Iranian women what to do. And you know, I get a lot of mail and some of the mail is from immigrant women, Germans as well as Asians. What they identify with in my book is the characters' being between roles. There isn't a role model for the "Jasmines" or the "Dimples." They have to invent the roles, survive and revise as best as they can. They don't have the consolation of the ready-made, approved, "seal of approval" of the feminist rhetoric. The ones that are being offered by the Ms. magazines are not at all appropriate; they just don't work in their lives, they don't ring true for their psychologies. Feminist rhetoric and feminist positions have changed in the ' 80 s, so that it is no longer quite as cantankerous. But I think black women will say the same thing about their relationship to white feminists.

TIR: It has become institutionalized at a certain level. It has become a product.

BM: Consumerized. Jasmine says that she would rather die before she tells the sob sisters about her rape by Half-Face. She doesn't want to talk about the things that are so very painful. So, in a way, I'm building a little joke about the continual self-reflexiveness of the American yuppies. But you see, something has happened. I was now aware of the parallels and contrasts between Dimple and Jasmine. Wife was written so long ago and that was a very controversial book. It was a very painful book for me.

TIR: Once it was out?

BM: Yes. The Village Voice reviewer loved it, Ms. magazine hated it. It was very confusing. I hadn't expected such controversy. The Tiger's Daughter was loved by everybody. But I had learned between Wife and Jasmine, and I had grown enough as a writer, to give the less sympathetic characters good lines too. Or to make the bad guys equally sympathetic or nearly equally sympathetic. So that the feminist, the white feminist, in $W i f e$, the one who has false teeth and who takes them off as a gesture, was a very brutally drawn character. Perhaps I have learned to make her a sympathetic character in her own right. A vulnerable person in her own way. Do you understand what I'm saying? It was more clear-cut in my mind who the enemy was in the earlier novel. Now I've sacrificed some of that rage and irony for fuller, more sympathetic, more rounded characters on both sides, both good guys and bad guys. 
TIR: Dimple seems much less able to make the leap into America than Jasmine does. Why do you think this is?

CB: Dimple, of course, is a prisoner of the ghetto. She never left that Flushing area in Queens.

BM: And she's educated, so that she's not operating on a purely instinctual level, as Jasmine is. She hasn't - just as I hadn't when I was writing that book-clearly found out what it is that she wants, or what it is she should be doing. So she ends in depression, madness, and murder. The murder at the end of the book is a misguided act. It was intended to be a self-assertive act on her part, but it's very ambiguous. Whereas with Jasmine, a village girl who's used to quite literally fighting the enemywhether it's a mad dog, or bad guys trying to accost her on the village lane as she's gathering firewood - there's a kind of gutsy village quality.

CB: In Indian terms, she's Punjabi. Dimple's Bengali.

BM: Punjabis are less into reflection. They're more action-oriented. Jasmine is a doer. Whereas Dimple, being a Bengali, and a college girl, is more of a thinker. And those complications brought on by too much thinking get to her. I can see now how, book by book - all this was happening without my noticing at the time-but book by book what I thought of as constituting a novel, or a relationship between author, character, and reader, all this has changed over the years. I have become more American, more North American. So it was very natural for me to write in an omniscient point of view about my characters in The Tiger's Daughter. I couldn't think of any other way. It was like $A$ Passage to India, or Jane Austen. I was parodying books that people who grew up in the postcolonial days - whether it was in Nigeria, or South Africa, or India - had read. We had a common storehouse of reading - overseas Cambridge reading-that I was building into the bankruptcy of that material in the book - that culture, that post-colonial, imported, British outpost life. Forester's Mau tank promises regeneration, whereas in The Tiger's Daughter it has shrunk to a little swimming pool. That kind of thing. By the time I came to write Wife, I couldn't automatically go back to omniscience; it didn't feel comfortable. I'm talking about 1972 versus 1975. Already I had changed so much as a writer that I needed to work with a limited third-person narrator. I feel that there's a lot more emotional intensity in the relationship between author and character with that tech- 
nique, and also less irony. What I've learned to do in Jasmine, I want to think, is create a kind of novel form where there's an intimacy required between reader and author. The reader has to put together many, many little parts. The author isn't making the big moral judgments. Jasmine isn't necessarily a good person. She's a blackmailer, she's forced into becoming a murderer. She dumps a good, crippled man who loves her, and leaves with someone else. So the reader is invited, is seduced - I want to thinkinto a kind of relationship with not just the character, but with the author.

TIR: That's a wonderful description. I think people feel that discomfort produced by the intimacy. They are seduced by Jasmine, and yet they resist her, too, because she isn't an entirely lovable person.

BM: I think she's lovable, but she's not moral in the conventional sense. She's moral in her own way. She knows what's right and wrong for her. But she ends up being a tornado who leaves a lot of debris behind.

TIR: She's remorseless, but there's no malice. At certain points in the book, I felt that the stories of the American characters were taking over. Jasmine seemed to have an incredible amount of sympathy for them, particularly the Moffitts.

BM: She's a love goddess, you see. Everyone's in love with her. She doesn't know how beautiful she is, I think, or what it is that's attractive about her. She's a life force in some way.

TIR: There's all that "wanting."

BM: Wanting. And believing. She believes that if you want, you might get. That is what's attractive to me about America. I'm coming out of a culture of despair, or cynicism. The cool thing to be is a cynic. Jasmine is a woman who hopes, and what America offers her-in spite of all the bad things that happen to her-is the hope that things will turn out all right. I think that's probably what's attractive about her to the Americans around her. Also, she wants to please. That's the feminine quality in her that doesn't jibe with American feminist rhetoric. Yet she's the one who, unlike (we're talking about the novel now), or far more than Wiley, or any other American woman, manages to leave a futile world, make herself over, pick up men, discard men, and make money. She's an uneducated village girl who is bright and has a career going. She can move on and make a life for herself. So she's an activist - or a woman of action-who 
ends up being far more feminist than the women on Claremont Avenue who talk about feminism.

TIR: Jasmine's caring seems to come from her sense of "wanting." She says, "In America, everything is in motion." But really, Jasmine's the one who is in motion. Bud is stuck. Darryl's stuck. She uproots her lover, splitting up the Moffitt family. She's the one who is the vortex, the one causing all the motion. That sense of love and compassion seems to come from this. She's in love with the country, and, in a way, she's revitalizing it, if it allows itself to be revitalized.

BM: Yeah, I would agree whole-heartedly with that. That "I want, I want." But for a village girl coming from a nothing family, from a nothing place, the audacity to even say "I want" is the biggest rebellion possible. I wanted it not to be simply grabbing, but revolution.

TIR: She says, "To want English was to want more than you had been given at birth. It was to want the world."

BM: Language. You had to learn to negotiate in the language of the country you had adopted. I really do feel that that's very much a part of the acquisition of power. I don't want to get into the language debates going on in the U.S., especially California. I understand why most liberal activists are for multi-culturalism, multi-lingual policies in schools, but if it is at the cost of creating ghettoes, if it is at the cost of keeping Jasmines locked in their own ghettoes within America, then I think that's a sad and wasted effort on the part of the activists.

TIR: The Jasmine character in the novel seems to be more self-aware, and less materialistic, than her predecessors.

BM: It was meant to be a lighter story. Then things happened I didn't expect. But I wanted to write about being Indian, third-generation, in a fluid society of the Americas. Where you may be technically a Brahmin, or you may be technically a Hindu, but you don't know anything about Hinduism. You've lost whatever that heritage was, but you hang on to certain antique words, phrases, and classifications. I wanted that sense of both openness and confusion of the minorities in the Caribbean. I wanted a new world that was totally multi-cultural. And I very deliberately set the story in V. S. Naipaul's birthplace because it was my "in" joke, challenging, if you like, Naipaul's thesis of tragedy being geographical. Naipaul's fiction seems to suggest that if you are born far from the center 
of the universe, you are doomed to an incomplete and worthless little life. You are bound to be, if you're born like a Jasmine, an Indian in the Caribbean, a comic character, you come to nothing. So I wanted to say, "Hey, look at Jasmine. She's smart, and desirous, and ambitious enough to make something of her life."

TIR: There seems to be a move toward an acceptance of the inevitability of violence in your later work. We go from hesitancy in Wife to the resolute action in Jasmine.

BM: It's a natural part by then. Having written the book on the Air India terrorism, I realized how pervasive violence is in this country. It's just under the skin of real life. It doesn't seem exotic, or external, anymore. I was coy, or decorous, a person of great decorum, when I was writing The Tiger's Daughter. Should I allow the main character in the novel to be deflowered, I had to ask myself. I absolutely didn't want that. And Clark said, when I showed him my manuscript, "The novel demands it, and you have to go through with it." And I thought, Oh, my God. Even though it's not autobiographical, people are going to assume that the same thing happened to me. It's that kind of violence that I was reluctant to write of in the early books.

CB: I think it raises an important question about how fiction writers can use their nonfiction to energize their vision, periodically. Writing Days and Nights and The Sorrow and the Terror have been very important to our fiction.

BM: Yes. "The Management of Grief" comes straight out of that later book. But I've gotten so much flak from some reviewers about the terrorism in Jasmine, with Suki turning up in New York.

TIR: You mean the implausibility of them being here?

BM: Yes. That's why I wish American publishers had published The Sorrow and the Terror. They would have known then about the network, how many Khalistani cells are operating here.

CB: They're picked up in Queens, they're picked up in New Jersey. TIR: In Jasmine, Bud says, as he and Jasmine pass an abandoned building, "I financed that place when the rate was such and such." And at the same time, Jasmine is thinking that a terrorist cell might be using it for other purposes. 
BM: Exactly.

TIR: But nobody will publish The Sorrow and the Terror in the United States?

BM: No, because there were no American victims on that flight. I want that in the interview, please. That American publishers have rejected that book because they have asked again and again if there were any American citizens involved.

TIR: With Darkness it was the same thing?

BM: It went out of print so fast. I think it's an important book, certainly important for me. The American publishers who were shown it didn't want to publish it. Their response was, who was going to read about immigrants? That was a bad word. The "I" word was a bad word in 1984-85. The book came out in 1985. So only about six hundred copies were imported into the U.S. by the Penguin office in New York, and it did extremely well because it was used in courses. The New York Times did a marvelous review, so the book had a secret cult life. But, at the time, people did not want to know about this particular minority. There were fashionable minorities, and unfashionable minorities. So Darkness disappeared kind of fast. It's out of print in the States, as are all the earlier books. But they're being reissued.

TIR: There is a sense of great love in your later works, for the characters and for the landscape, the New World.

BM: That happened somewhere between Darkness and The Middleman. Darkness was a breakthrough book in the sense that I was writing about changes among the immigrants. It was still darkness, after all, and I was coming out of that whole Canadian mess. I want to think that writing that book was invigorating for me. But for many of the characters, things didn't work out when they transplanted themselves into a new culture. But by the time I came to write The Middleman, I was exhilarated, my vision was more optimistic. I knew that I was finally where I wanted to be. And though I was moving in degrees of acculturation, the overall authorial vision is, I hope, consistent.

Let me get back to the sense of the novel for a moment. Because my characters have a 19th-century density to their lives, my writing has to show the fullness of those lives. But I'm an American writer, writing in the late 1980s. So I had to find a new form, as well as new sentences, to 
create these very un-American characters, and to fuse them with my own pre-American sense of what constituted a full life. So the novels are structured - or Jasmine is structured - in very short takes. I've tried to cram in a sense of the entire world, whether it's a little village in Punjab, or boats coming off the coast of Ecuador - which is a big center for circuitous Indian immigration. New York, the Midwest, California - they're all in the book because that's the way our lives are constantly being shuttled around. I've exchanged so many cultures, so many citizenships in twentyfive years, but still, this action has to be very compressed because I don't want to write a Thackerian or Dickensian novel. Then I would be mimicking the British form. I'm interested in finding the right form for me and my characters, who are the kinds of Americans who haven't been written about before. So the characters of, say, an Ann Beattie are signiificantly different from mine because they've not been dislocated in such severe and traumatic ways. An oceanic or social view rarely creeps into contemporary American fiction. It is simply - well, not simply, predominantly-fiction about personal relationships. Even someone like Raymond Carver, whose work I admire very, very much, and whose stories are obviously meant to be tragic, is talking about small disappointments. Whereas in talking about Jasmine's life, I'm really talking about the history of current America too. So a sentence about a man in Osage beating his wife with a spade and hanging himself later is as important as Jasmine's story. People like me, because we've come from the Third World, have a very different notion of what constitutes the novel. A social and political vision is an integral part of writing a novel, of being a novelist. Whereas I think for contemporary American writers, fiction exists only in a vacuum of personal relationships.

TIR: How does your work begin to happen for you?

BM: When the writing is going well, the characters take over, and they dictate what is going to happen to them in the scene. In "Buried Lives," for instance, I thought, when I started out, that the Sri Lankan, Tamil, was going to die off the coast of Nova Scotia. There had been two boatloads of refugees who had been put by unscrupulous captains into boats which sank there. They just deserted them when they saw the Coast Guard coming. So I assumed that this would be how this man would end in my story. But the guy wouldn't get on the boat. He found ways of hanging around, staying on in Germany. Then he found a girlfriend and 
she gave him his necessary visa papers. So I really do hear a voice when things are going well. Then I read something about athletes being "in the zone." And I said, "My God, that's really what's happening in the best of my work." I immediately identified with that idea. I find that I throw away the stuff I've written when I have not entered "the zone." I am like a medium. I am both inside and outside the character. I'm hearing this voice that's writing itself. The scenes work themselves out, and each project has its own momentum. I am forced to write so fast, and with such intensity, because it's always during vacations. I'm working twenty-one hour days with everything bubbling in my head. So in the middle of the night these things are working themselves out. Though I may have gotten up out of my chair.

TIR: During that time you're sensitive to absorbing things, like photographs?

BM: Yes. Everything works its way in. And I don't waste, it seems. Any overheard conversations, any faces seen-I never know when they're going to work their way into my fiction. I don't keep notebooks, but these details just pop up in the work.

TIR: The book becomes like a magnet?

BM: Yes. Maybe that's exactly what I've been saying about how scraps of conversation during certain periods will feed themselves into the book. It all seems appropriate; I know how to use it all. Or every face will suggest a compulsive story.

TIR: Earlier in your career you talked about "voice" being your prime aesthetic.

BM: Finding the right voice, right. That's something that I came to as a result of talking to, or listening to, Clark. The sense of voice being the way one controls fiction. Voice can be the sum total of every artistic trick in your bag. It's how to use texture, how to use metaphor, how to choose the right point of view, the point of view character, and therefore the idioms, the language. Knowing when to withhold information, when to disclose, etc. Now I realize that in addition to that, voice, for me, is the physical, or actual, hearing of the main character speak. The rest happens automatically. It is all happening without my having to think about it. TIR: What about essay writing? Is "the zone" involved in that kind of writing, too? 
BM: No. I know when I'm doing well, and when the ideas are simply not clear. But it's not the same physiological change that happens to me when I'm writing fiction that I'm really satisfied with. Essays seem to me to be coming out of a different part of my brain. It's not that same internal compulsion. I won't take on a subject that doesn't interest me. I will only do it if I feel I have a special angle on it, and the subject matter is sufficiently interesting to me. I don't come in with preconceived notions of what I'm going to find. But it's a very different kind of writing. It's Mukherjee writing, and Mukherjee assessing and analyzing, rather than something else. I don't have that intermediary. I haven't become someone else. I must not become someone else when I'm writing an essay. I think Clark is such a good essay writer. I've learned a lot from reading his essays. And Resident Alien seems to me such a new concept for a book. You have the autobiographical essays, and then the inventions of autobiography. I find it very hard to write autobiography. I'm supposed to write a piece for a place that Clark did an autobiographical piece for. And I said yes when they asked me, and I just can't seem to sit down and write about myself. I've done many essays since and I've said yes to doing an essay on the art of healing, but to write about myself without the disguises ... I don't know.

TIR: Do you work on a word processor?

BM: Yes. "Angela" was done on an IBM Selectric. "The Middleman" and Jasmine were done on the screen. But even when I'm on the typewriter, I don't know how stories are going to turn out. In Jasmine, for example, I didn't know she was going to leave Bud at the end of the novel. She just up and went! Because she got bored with the situation. Not bored. She felt it was a regression, like going back to village life, a life of duty and devotion, to stay on caring for this crippled fellow. The frontier was out there, beckoning. She just left. Then I had to beef up Taylor in the second rewrite, in order to justify her leaving. Plus make Karen, who had been hanging around anyway, be there to look after Bud.

TIR: I didn't really look at it that way. I thought she was going after her adopted son.

BM: Yes, that too.

CB: That was part of the replotting, too, to put him out there in California.

BM: What I had wanted was the sense of reconstituting new American 
families, so that Bud and Jasmine and Yogi make up one kind of family, but it gets wilder and wackier in that last scene where Jasmine is pregnant by Bud, yet she's going off with Taylor, and the adopted Duff, to link up with Yogi and his sister.

TIR: Maxine Hong Kingston has talked about our needing a "global novel." Do you see your fiction going that way?

BM: Maybe fiction is going that way, but I would never start out with an agenda that I must sit down and write a "global novel." A character has to come to me urgently-a scene, a sentence. The fiction itself must seem urgent to me. I don't like to have the social prescription, or the political prescription, that I am then trying to flesh out. I think there's a propaganda novel or thesis novel that can be important, but the concept strikes me as necessarily lacking life. It doesn't come from the guts, the heart, of the writer. And I don't see at all why good fiction has to be global fiction. It's the lot of some writers, who are-because of the accidents of historyforced to be on the move. Then there are the Richard Fords and the Russell Banks who may be writing of small town America, but with great gifts, and great compassion. It's making life important, making a single life important, rather than having to have a prescription for the global ills which afflict us. 